Journal : JMMR (Jurnal Medicoeticolegal dan Manajemen Rumah Sakit), 10 (1): 35-45, April 2021

Website : http://journal.umy.ac.id/index.php/mrs

DOI $\quad$ : https://doi.org/10.18196/jmmr.v10i1.10829

\title{
Physical Activity Patterns in Lecturers During Covid-19 Pandemic: A Qualitative Study
}

\section{Mahendro Prasetyo Kusumo}

Correspondence Author: mahendro_prasetyo@umy.ac.id

Masters of Hospital Administration postgraduate program Universitas Muhammadiyah Yogyakarta, Bantul, Indonesia

\section{N D E X I N G \\ Keywords: \\ T2DM;}

Lecturer;

Perception;

Physical activity.

\begin{abstract}
A B S T R AC T
Sedentary lifestyle is associated the work of lecturer. Sedentary lifestyle is one of the Non-Communicable Diseases (NCDs) causes. This study aims to explore physical Activity Patterns in Lecturers during COVID-19 Pandemic. This study used qualitative research from July to September 2020. Interviews were conducted to sixteen lecturers which is divided into two groups. The data collection was through in-depth interview techniques by telephone. Participants were determined by purposive sampling. The number of participants is seventeen. The analyzing data process through transcripts, coding, and determining themes was performed using In-Vivo software. Credibility criteria and triangulation is done to ensure valid data. The results of this study show that the desired pattern of physical activity is to use free time, even though they have difficulty managing time and lack of motivation. There is a need for health policy at the university to apply a healthy lifestyle, such as walking between buildings, using stairs, doing independent exercise between working hours, procuring bicycles for transportation between buildings and maximizing sports facilities management. Conclusion: The physical activity pattern of lecturers mostly utilizes free time to walk between buildings, go to mosques and long distances parking to the premises in the university environment.
\end{abstract}

Kata kunci:

DMT2;

Dosen;

Persepsi;

Aktivitas fisik
Gaya hidup menetap dikaitkan dengan pekerjaan dosen. Gaya hidup menetap adalah salah satu penyebab Penyakit Tidak Menular (NCD). Penelitian ini bertujuan untuk mengeksplorasi Pola Aktivitas Fisik Dosen saat Pandemi COVID-19. Penelitian ini menggunakan jenis penelitian kualitatif mulai bulan Juli hingga September 2020. Wawancara dilakukan terhadap enam belas dosen yang terbagi dalam dua kelompok. Pengumpulan data dilakukan melalui teknik wawancara mendalam melalui telepon. Partisipan ditentukan secara purposive sampling. Jumlah partisipan dalam penelitian ini adalah tujuh belas. Proses analisis data melalui transkrip data, pengkodean, dan penentuan tema dengan menggunakan software In-Vivo. Kriteria kredibilitas dan triangulasi dilakukan untuk memastikan validitas data. Hasil penelitian ini menunjukkan bahwa adanya kesulitan dalam mengatur waktu, kurangnya motivasi and pemanfaatan fasilitas UMY. Perlu kebijakan kesehatan untuk menerapkan perilaku hidup sehat, seperti berjalan kaki antar gedung, menggunakan tangga, melakukan senam mandiri di antara jam kerja, pengadaan sepeda untuk transportasi antar gedung, dan memaksimalkan pengelolaan fasilitas olahraga. Kesimpulan: Sebagaian besar pola aktivitas fisik dosen dengan cara memanfaatkan waktu luang untuk berjalan antar gedung, pergi ke masjid dan parkir jarak jauh menuju tempat di lingkungan Universitas.

C) 2021 JMMR. All rights reserved

Article history: Received 2021-01-11; Revised 2021-02-15; Accepted 2021-04-12

\section{INTRODUCTION}

Non-Nommunicable diseases (NCDs), such as cardiovascular and respiratory diseases, diabetes mellitus (DM) and cancer has had a significant impact on their health during pandemic COVID-19. Restrictive measures during the COVID-19 pandemic have presented a 
challenge to maintaining appropriate levels of physical activity and accessing healthy food. Significantly reduced physical activity, including travel to work and other places, exercise and sports for recreational purposes, may lead to an increase in obesity and risk of diabetes and cardiovascular diseases. This highlights the need for focusing on the unintended effects of the COVID-19.

Non-Communicable disease (NCD) is a metabolic disease caused by unhealthy behavior. NCD is the leading cause of death globally and responsible for 38 million deaths (68\%) in the world in 2012. NCD causes more than $40 \%$ of premature deaths in populations under 70 years and the majority occurs in low and middle-income countries (World Health Organization, 2014). Diabetes Mellitus (DM) is one of the third highest NCD in the world (World Health Organization, 2017, WHO, 2014). World Health Organization reported that 422 million people worldwide have DM in 2014 (World Health Organization, 2018a). people with Diabetes Mellitus in adults in Indonesia reach $6.2 \%$ with a total of 10,681,400 cases (International Diabetes Federation, 2020). The high morbidity rate causes economic impacts due to lost productivity and high medical costs (World Health Organization, 2016). Diabetes Mellitus is one of the three highest non-communicable diseases that caused economic losses of around USD 156,076 in 2010 and the DM costs consist of direct and indirect costs (Liyanage, 2017).

Globally, Diabetes Mellitus (DM) is one of the third highest NCD in the world (World Health Organization, 2017), (WHO, 2014). World Health Organization reported that 422 million people worlwide have DM in 2014 (World Health Organization, 2018a). people with Diabetes Mellitus in adults in Indonesia reach $6.2 \%$ with a total of 10,681,400 cases (International Diabetes Federation, 2020). Diabetes Mellitus with complications is the cause of death from non-communicable diseases in Indonesia around 6.7\% (Kemenkes, 2016). The high mortality rate causes economic impacts due to lost productivity and high medical costs (World Health Organization, 2016). Diabetes Mellitus is one of the three highest noncommunicable diseases that caused economic losses of around USD 156,076 in 2010 and the DM costs consist of direct and indirect costs (Liyanage, 2017).

Lack of physical activity or sedentary behavior is the leading cause of the high prevalence of NCD's (World Health Organization, 2017). Sitting for more than eight hours per day (continoused sedentary behavior) increases the risk of developing NCD. Forty percent of men and forty eight percent of women who live in developed countries do not do sports with a moderate intensity (at least 150 minutes per week) (World Health Organization, 2010). Previous research has explained that sedentary behavior is found among lecturers. Most of them spend their time working sitting down (World Health Organization, 2010).

World Health Organization encourages health promotion to be applied in every setting, one which is health promotion in educational environment. Institution of higher education should concerned about promoting health among student, staff, and lecturer (World Health Organization Europe, 1998). The healthy living culture through physical activity in the university environment is one of the principles that must be followed by every lecturer (Physical Activity Guideline Advisory Committee, n.d.). Tthrough the role modeling method, it can improve the lecturers' and students' healthy behavior. One of the obstacles in implementing this principle is time constraints and difficulty managing time (Leininger \& Kent J, 2016). 
World Health Organization has declared the novel coronavirus (COVID-19) outbreak a global pandemic on March 11, 2020. Over 37 million COVID-19 cases and 1 million deaths have been reported globally from 30 december 2019 through 11 October 2020 (World Health Organization, 2020a). The Government of the Republic of Indonesia has Reported 598,933 persons with confirmed COVID-19 as of 10 December 2020 and there have been 18336 deaths related to COVID-19 (World Health Organization South-East Asia Indonesia, 2020). Amid the widespread spread of the coronavirus disease (COVID-19), the government has made efforts to prevent the spread by issuing policies on limiting direct contact. It has restricted lecturers from doing physical activity and being one of the obstacles in carrying out physical activities at the university. Based on these conditions, the investigator wanted to explore physical activity patterns in lecturers Universitas Muhammadiyah Yogyakarta during the COVID-19 Pandemic Era.

\section{RESEARCH METHOD}

This study was conducted a qualitative method which content analysis. The participants were determined by purposive sampling with the maximum variation approach. If the data is homogeneous, the investigator will finish collecting the data. The number of participants is ten females and seven males. Respondents were selected based on inclusion criteria: being willing to be respondents, being lecturers for at least two years, permanent UMY's lecturers and aged 30 to 65 . Participants were purposefully selected to represent various scientific field backgrounds (social groups and science groups). They were also required to be 'insufficiently active' to find the cause of the insufficiently active', which was defined as not achieving 30 minutes of moderate physical activity on at least seven days per week, according to the National Physical Activity Guidelines.

Participants were initially contacted by phone to establish eligibility and informed consent. They were interviewed in their home or at a convenient location by a single interviewer. These formal interviews took about 45 to 60 minutes to complete. Permission was sought for recording the interviews and a fifty-thousand-rupiah gift voucher was offered to each subject as an incentive. Interview guideline developed based on literature review and our experience in physical activity research. The interview focused on perceptions of during physical activity at university.

Each interview was fully transcribed verbatim and read at least six times in order to establish a broader understanding of the meaning of the participant's dialogue, during which qualitative content analysis was conducted. The analysis process involved the breaking down of transcribed data into smaller units. Units or topics of information were sentences and occasionally paragraphs that conveyed discrete information. Paragraphs were used so that the contextual meaning was not lost. The data were then coded according to the content and then the material was categorized. The coded data were managed by open code. The categorized data were organized around two major headings: (a) beliefs and perceptions of physical activity and (b) physical activity pattern during COVID-19. In ensuring the study validity, triangulation was carried out through group discussions with six lecturers. Criteria for credibility is done by directly observing the behavior of lecturers for six months. On the other hand, triangulation was carried out through group discussions with six lecturers. Investigator guaranteed the research results' validity by conducting member checking and an audit trail. Ethical approval 
is published by the Health Research Ethics Committee Universitas 'Aisyiyah Yogyakarta (No 1633/KEP-UNISA/V/2020).

\section{RESULT AND DISCUSSION}

This study show that several essential codes were found. These essential codes were identified and then grouped into three themes: 1) beliefs and perceptions of physical activity, 2) physical activity pattern during COVID-19, and 3) Barriers lecturers to physical activity.

\section{Barriers lecturers to physical activity}

Some of the obstacles for lecturers in carrying out physical activities in the UMY campus environment included difficulty managing time and tight teaching schedules. The following are quotes from the informants:

"The time is not suitable for sports; sometimes, it collides with other events ..." (Non-social science lecturer)

"... I think the workload for the lecturers is quite high so that sometimes, I am tired of thinking about what to do ..." (Social science lecturer)

"The sports schedule on campus isn't in accordance with the free time I have; it often collides with teaching, meeting, and guiding students" (Non-social science lecturer)

Some other obstacles were feeling lazy and had no intention. The following is an excerpt from the informants' statements:

"... There has not been a strong intention to spend time on sports yet ..." (Non-social science lecturer)

Activities as a lecturer were more in the room, sit more, and more activities were only in the room. The following are excerpts from the informants' statements:

"... my activities are mostly sitting in the air-conditioned room facing the computer or laptop, and I experience it every day." (Social lecturer)

"... Some of my work has to sit, for example, discussions, giving lecture materials, and guidance ..." (Non-social science lecturer).

Activities carried out using tools so that lecturers did not get tired quickly. The following is a quote from the informant:

"... Time is tight, so I prefer to use the lift facility to get to the destination faster" (science lecturer)

Facilities' utilization to support physical activity was still not optimally used due to time constraints and laziness. The following is an excerpt from the informant's statement:

"... Various sports centers such as a gym center, badminton court, futsal field, soccer field, and running tracks have not been maximally used as sports facilities... " (Non-Social science lecturer)

\section{Physical activity during COVID-19 Pandemic}

The COVID-19 pandemic conditions require not crowding so that physical activity was carried out independently. The following are quotes from the informants: 
"For me, I exercise at home with independent exercise; because if I leave the house, there is a risk of catching COVID... "(Non-social science lecturer)

"... Get used to going up and downstairs while on campus to burn calories in the body ..." (Nonsocial science lecturer)

"... Only now is the problem if we cannot exercise together on campus, because there are restrictions on crowding ..." (Social science lecturer)

Several policies can be implemented regarding the COVID-19 pandemic conditions, including physical activities carried out independently. The following is a quote from the informant:

"I think in the COVID-19 pandemic era, it is difficult to implement mass gymnastics, even with health protocols ... what is possible is to implement walking in the university environment ...."

One form of strategy during COVID 19 pandemic to improve healthy living behavior is by department that focuses on managing a healthy lifestyle. The following is a quote from the informant:

"During the Covid-19 pandemic, there should be a department that focused on explaining the importance of physical activity, for example walking, cycling"

\section{Physical activity policy at the university}

The sports facilities' utilization and management can also be improved and optimized. The following is a quote from the informant:

"... maximizing and optimizing existing facilities..." (Social lecturer)

The COVID-19 pandemic means that many of us are staying at home and sitting down more than we usually do. It's hard for a lot of us to do the sort of exercise we normally do. It's even harder for people who don't usually do a lot of physical exercise. Regular physical activity benefits both the body and mind. It can reduce high blood pressure, help manage weight and reduce the risk of NCDs (World Health Organization, 2020b). Unfortunately, modern lifestyle behaviors promote physical inactivity. These poor lifestyle behaviors are intensified by social distancing and self-imposed or government mandated quarantine measures intended to reduce COVID-19 spread. These circumstances pose significant challenges for remaining physically active. During COVID-19 pandemic, all socioeconomic groups, ethnicities, and ages should maintain good health by following the WHO PA recommendations of 150 minutes of moderate-intensity or 75 minutes of vigorous-intensity PA per week, or a combination of both (World Health Organisation, 2020).

In 2016, the government implemented a Healthy Indonesia program that focused on healthy living habits to control NCD (Kementrian Kesehatan Republik Indonesia, 2016), (Kementrian Kesehatan Republik Indonesia, 2015). On the other hand, these various programs have not provided maximum results, especially in preventing NCDs. Some strategies healthy lifestyle implementation program can promote healthy living to prevent and manage DM (Kusumo et al., 2020a). Lack of physical activity is One of the reasons this program hasn't been maximized (World Health Organization, 2010). World Health Organization recommends every adult to do physical activity at least 150 minutes per week or 30 minutes per day with moderate intensity (WHO, 2014), (National Institutes of Health, 2002, World 
Health Organization, 2013). Two intervention approaches can be done to change a person's lifestyle: community-based intervention and individual-based intervention (Lorig et al., 2009, Kramer et al., 2011, (Roux et al., 2008, Plotnikoff et al., 2013).

Table 1. Essential coding, category and themes

\begin{tabular}{|c|c|c|c|}
\hline No & Coding & Category & Theme \\
\hline 1 & $\begin{array}{l}\text { More time indoors } \\
\text { Sitting for long periods of time } \\
\text { It's hard to manage time } \\
\text { Activity only in the unit } \\
\text { Solid teaching schedule }\end{array}$ & bad habits on campus & \multirow[t]{2}{*}{$\begin{array}{l}\text { Barriers lecturers to } \\
\text { physical activity }\end{array}$} \\
\hline 2 & $\begin{array}{l}\text { Pain to moderate activity } \\
\text { Lazy for activity } \\
\text { Choose to use the elevator so you don't get tired }\end{array}$ & low Intention & \\
\hline 2 & $\begin{array}{l}\text { Walk between buildings } \\
\text { Climbing up the stairs } \\
\text { Minimizes sitting while teaching } \\
\text { Look for a parking space that is far away } \\
\text { Diligently go to the mosque on foot }\end{array}$ & $\begin{array}{l}\text { Make use of time } \\
\text { between activities on } \\
\text { campus }\end{array}$ & \multirow{3}{*}{$\begin{array}{l}\text { Physical activity } \\
\text { during COVID-19 } \\
\text { Pandemic }\end{array}$} \\
\hline 3 & $\begin{array}{l}\text { Jogging } \\
\text { Swimming } \\
\text { bicycles }\end{array}$ & Individual sport & \\
\hline & futsal, gymnastics, badminton and football & Group sports & \\
\hline 4 & $\begin{array}{l}\text { 1. Provide a fitness center and gym } \\
\text { 2. Provide badminton court } \\
\text { 3. Provides futsal and soccer fields } \\
\text { 4. improve pedestrian paths } \\
\text { 5. Procurement of bicycles for transportation } \\
\text { between buildings }\end{array}$ & $\begin{array}{l}\text { Implementation policy } \\
\text { of healthy life for } \\
\text { lecturers }\end{array}$ & $\begin{array}{l}\text { followed the } \\
\text { physical activity } \\
\text { policy at the } \\
\text { university }\end{array}$ \\
\hline
\end{tabular}

Previous study showed community-based intervention significantly increased self-efficacy in social support in patient with T2DM (Kusumo et al., 2020b). The setting-based approach to health promotion can enhance the university's contribution to improving population health. This can be done by protecting the health and promoting the wellbeing of students, staff, lecturers and the wider community through their policy approaches and practices; furtherenhance teaching and research activities related to health promotion; further develop health promotion alliances and reach out to communities (World Health Organization Europe, 1998)

This study shows that lecturers' obstacle to doing physical activity was a lack of motivation and intention. Most of the lecturers lazy doing physical activities. The kinds of barriers to physical activity caused low participation in physical activity. Previous study has explained that lack of motivation is one of the most important factors in carrying out a physical activity (Hunter et al., 2018).

Most of the lecturer sedentary lifestyle in the room. It caused a high risk of developing NCDs (Kusumo, 2020). Previous research has explained that most lecturers didn't have time to do physical activity or prepare healthy food. On the other hand, Lecturers must provide examples of healthy behavior. Lecturers act as role models for students in carrying out healthy living behaviors. Many studies have stated that the lecturers' attitudes and behavior affect the 
students' academic sustainability (Leininger \& Kent J, 2016). The poor of time management is the main reason for lecturers to do physical activity. It was caused by the high workload and busy teaching schedule so that the teaching staff felt tired. The previous study, teaching schedules are one of the obstacles in carrying out physical activity. There is a need for policies regarding sports obligations outside of working hours and a rational schedule (Leininger \& Kent J, 2016).

Sports policies in universities increase employee participation in physical activities to improve employee health and fitness (Hunter et al., 2018). Previous studies showed that exercise intervention in the workplace have effect on employee physical activity and health (Arena et al., 2013), (Rla et al., 2020). Lifestyle modification can help the employee to maintenance their weight (Dejoy et al., 2011). Health promotion university have since evolved to incorpotate physical activity programs, health education, smoking cessation, weigh loss and stress management (Hill-mey et al., 2015).

Universitas Muhammadiyah Yogyakarta is one of the educational institutions with a complete health facility. Some of the facilities owned by UMY were a fitness center, jogging track, soccer field, badminton field, and weekly exercise program, however utilization has not been optimal. Health policies University need to be implemented to increase motivation and intention. Previous research has explained that the number of sessions and variations in time could overcome lecturers' time constraints (Leininger \& Kent J, 2016). The policies implemented during COVID-19 pandemic need to refer health protocols. Some strategies that can be done in doing physical activity independently are walking, going up and downstairs, and using bicycles to move between buildings by using a mask. Increasing intention in using ladder facilities can be done by changing the stairs' appearance, such as being painted, repainted, or giving motivational sentences. Besides, information is needed regarding existing facilities, such as a jogging track plan to increase interest in physical activity (Sharma et al., 2016).

Strategies that can be used in the workplace are designing one-on-one training sessions with an instructor. Lecturers are encouraged to be accountable for their status in carrying out physical activities based on policies. This encourages employees and makes it easier to assess the achievement of a physical activity program (Hunter et al., 2018). Effective program require ability to assess the need for services, attract participants, use behavioral theory for foundation, can measure the impact program. Management and senior leadership support, dedicated staffing and resources, incentives and reward also needed (Goetzel \& Ozminkowski, 2008). Helath promoting universities should establish internal structures to develop and implement the program include a project steering group, a project coordinator and a role for health related support services and other potential stakeholders (World Health Organization Europe, n.d.). Policymaking can be one strategy in increasing physical activity habits in the university environment. The support from the leadership in providing examples in doing physical activity regularly can increase lecturers' motivation to perform regular physical activity. Health behavior department in the university is also one strategy that can be implemented.

\section{CONCLUSION}

Lack of managing time, motivation, and utilization of sports center facilities were barriers in carrying out physical activities in lecturers. There is a need for policies to manage healthy 
living behavior in the university environment. The policy to walking between buildings, using stairs, procuring bicycles for transportation between buildings, and managing sports facilities to the fullest. This policy also allows the independent use of physical activity patterns that can be implemented.

Finally, the expressed desires for involvement in various types of physical activity during COVID-19 pandemic should be acknowledged, as well as the feasibility of developing a range of modified activity types suitable for lecturers. An increased focus on making physical activity during COVID-19 pandemic a joyful experience would increase participation. Physical activity must become the 'policy' so that lecturers feel supported in their pursuits.

\section{ACKNOWLEDGMENT}

The authors would like to thank Universitas Muhammadiyah Yogyakarta and the lecturers of Universitas Muhammadiyah Yogyakarta.

\section{REFERENCE}

Arena, R., Guazzi, M., Briggs, P. D., Cahalin, L. P., Myers, J., Kaminsky, L. A., Forman, D. E., Cipriano, G., Borghi-silva, A., Babu, A. S., \& Lavie, C. J. (2013). Promoting Health and Wellness in the Workplace: A Unique Opportunity to Establish Primary and Extended Secondary Cardiovascular Risk Reduction Programs. Mayo Clinic Proceedings, 88(6), 605617. https://doi.org/10.1016/j.mayocp.2013.03.002

Dejoy, D. M., Parker, K. M., Padilla, H. M., Wilson, M. G., Roemer, E. C., \& Goetzel, R. Z. (2011). Combining Environmental and Individual Weight Management Interventions in a Work Setting: Results From the Dow Chemical Study. American College of Occupational and Environmental Medicine, 53(3). https://doi.org/10.1097/JOM.0b013e31820c9023

Goetzel, R. Z., \& Ozminkowski, R. J. (2008). The Health and Cost Benefits of Work Site Programs. Annual Review of Publich Health, 29, 303-323. https://doi.org/10.1146/annurev.publhealth.29.020907.090930

Hill-mey, P. E., Kumpfer, K. L., Merrill, R. M., Reel, J., Hyatt-neville, B., \& Richardson, G. E. (2015). Worksite health promotion programs in college settings. Journal of Education and Helath Promotion, 4(March), 1-7. https://doi.org/10.4103/2277-9531.154019

Hunter, J. R., Gordon, B. A., Bird, S. R., Benson, A. C., Hunter, J. R., Gordon, B. A., Bird, S. R., Benson, A. C., Hunter, J. R., Gordon, B. A., Bird, S. R., \& Benson, A. C. (2018). Perceived barriers and facilitators to workplace exercise participation. International Journal of Workplace Health Management. https://doi.org/10.1108/IJWHM-04-2018-0055

International Diabetes Federation. (2020). IDF Western Pacific Members.

Kemenkes. (2016). NCD Prevention and Control in Indonesia. 
Kementrian Kesehatan Republik Indonesia. (2015). Buku Panduan Gerakan Masyarakat Hidup Sehat (Pertama).

Kementrian Kesehatan Republik Indonesia. (2016). Profil Kementrian Kesehatan. 1-7.

Kramer, M. K., McWilliams, J. R., Chen, H. yu, \& Siminerio, L. M. (2011). A CommunityBased Diabetes Prevention Program: Evaluation of the Group Lifestyle Balance Program Delivered by Diabetes Educators. The Diabetes Educator, 37(5), 659-668. https://doi.org/10.1177/0145721711411930

Kusumo, M. P. (2020). Implementasi Promosi Kesehatan di Rumah Sakit. In Reference Book (First edit). Lembaga Penelitian, Publikasi dan Pengabdian Masyaraka, Universitas Muhammadiyah Yogyakarta.

Kusumo, M. P., Hendrartini, J., Sufro, Z. M., \& Dewi, F. S. T. (2020a). A Qualitative Study to Explore the Perception of Patients Towards Diet in Javanese Culture. Enfermería Clinica, 30, 183-187. https://doi.org/10.1016/j.enfcli.2020.06.041

Kusumo, M. P., Hendrartini, J., Sufro, Z. M., \& Dewi, F. S. T. (2020b). Theater performing art: A strategy to improve self-efficacy and social support in patient with type 2 diabetes mellitus (T2DM). Journal of Global Pharma Technology, 12(6), 70-76.

Leininger, L. J., \& Kent J, A. (2016). Differences in Physical Activity Participation between University Employees with a Worksite Health Promotion Program and Those Without International Journal of Workplace Health Management Article information: July. https://doi.org/10.32398/cjhp.v11i1.1519

Liyanage, L. (2017). Economic Burden of Diabetes Mellitus Economic Burden of Diabetes Mellitus. Journal of Social Statistic 2017.

Lorig, K., Ritter, P. L., Villa, F. J., \& Armas, J. (2009). Community-based peer-led diabetes selfmanagement: a randomized trial. The Diabetes Educator, 35(4). https://doi.org/10.1177/0145721709335006

National Institutes of Health. (2002). The Diabetes Prevention Program (DPP): Description of lifestyle intervention. Diabetes Care, 25(12), 2165-2171. https://doi.org/10.2337/diacare.25.12.2165

Physical Activity Guideline Advisory Committee. (n.d.). Physical Activity Guidelines Advisory Commitee Report, 2008. Department of Health and Human Services. https://doi.org/10.1111/j.1753-4887.2008.00136.x

Plotnikoff, R. C., Costigan, S. A., Karunamuni, N. D., \& Lubans, D. R. (2013). Communitybased physical activity interventions for treatment of type 2 diabetes: A systematic review 
with meta-analysis. Frontiers in Endocrinology, 4(JAN), 1-17. https://doi.org/10.3389/fendo.2013.00003

Rla, F., Cumpston, M., Albarqouni, L., Sa, C., \& Peeters, A. (2020). Workplace pedometer interventions for increasing physical activity. Cochrane Databese of Systematic Reviews, 7. https://doi.org/10.1002/14651858.CD009209.pub3.www.cochranelibrary.com

Roux, L., Pratt, M., Tengs, T. O., Yore, M. M., Yanagawa, T. L., Van Den Bos, J., Rutt, C., Brownson, R. C., Powell, K. E., Heath, G., Kohl, H. W., Teutsch, S., Cawley, J., Lee, I. M., West, L., \& Buchner, D. M. (2008). Cost Effectiveness of Community-Based Physical Activity Interventions. American Journal of Preventive Medicine, 35(6), 578-588. https://doi.org/10.1016/j.amepre.2008.06.040

Sharma, S. V, Winston, C., Vinu, P., William, J., Brett, B., Mary, P., Sharma, S. V, Winston, C., Vinu, P., William, J., Brett, B., Mary, P., Montgomery, C., Feltovich, M., Griffith, J., Alfaro, V., \& Pompeii, L. A. (2016). Evaluation of worksite policies and practices promoting nutrition and physical. International Journal of Workplace Health Management, 9(1), 46-62.

WHO. (2014). Global Status Report On Noncommunicable Diseases 2014.

World Health Organisation. (2020). Global health strategy. http://library1.nida.ac.th/termpaper6/sd/2554/19755.pdf

World Health Organization. (2010). Global recommendations on physical activity for health. WHO Press.

World Health Organization. (2013). Media centre Diabetes. Diabetes. www.who.int/mediacentre/factsheets/fs312/en/

World Health Organization. (2014). Non-Communicable Disease.

World Health Organization. (2016). Global Report on Diabetes.

World Health Organization. (2017). Noncommunicable diseases. Noncommunicable Diseases; World Health Organization.

World Health Organization. (2018a). Diabetes Mellitus.

World Health Organization. (2018b). Indonesia. In Diabetes country profiles. https://www.who.int/diabetes/country-profiles/bra_en.pdf

World Health Organization. (2020a). Coronavirus disease. World Health Organization, 2019(March), 2633. https://doi.org/10.1001/jama.2020.2633 
World Health Organization. (2020b). The COVID-19 pandemic and physical activity. Sports Medicine and Health Science, 2(2), 55-64. https://doi.org/10.1016/j.smhs.2020.05.006

World Health Organization Europe. (n.d.). Health Promoting Universities Concept, Experiences and Framework for Action (A. D. Tsouros, G. Dowding, J. Thompson, \& M. Dooris (eds.)). WHO Regional Office for Europe.

World Health Organization South-East Asia Indonesia. (2020). Update on coronavirus disease in Indonesia. Coronavirus Disease. https://www.who.int/indonesia/news/novelcoronavirus 